\title{
Brote severo de $E$. coli productora de Shiga toxina (STEC) en Alemania: ¿Es el resultado de la promiscuidad de la $E$. coli?
}

\author{
Shiga toxin producing $E$. coli (STEC) outbreak in Germany: is the result of $E$. coli promiscuity?
}

El reciente brote de Escherichia coli productora de shiga toxina (STEC) serotipo O104:H4 en Alemania y otros países de Europa ha puesto en evidencia, una vez más, que las bacterias pueden intercambiar o adquirir material genético de otras bacterias para convertirse en cepas más virulentas.

Desde inicios del mes de mayo de este año, se desencadenó en Alemania un brote de STEC, también conocido como E. coli enterohemorrágica (EHEC) o E. coli productora de verotoxina (VTEC), afectando en la Comunidad Europea hasta la fecha a más de 3000 personas, de las cuales aproximadamente 800 han desarrollado una complicación severa de esta infección conocida como síndrome urémico hemolítico (HUS), ocurriendo más de 30 fallecimientos (1). Las cifras de casos afectados y casos letales, corresponden a lo reportado hasta el 10 de junio, del presente año. A la fecha de la publicación de esta editorial, probablemente estos números sean mayores, aunque esperamos que no mucho más. El control del brote ha sido difícil, dado que a la fecha no se ha podido aún identificar la fuente. Las investigaciones epidemiológicas en Alemania apuntan a que el brote está asociado a verduras no cocidas, siendo los vehículos más sospechosos los frijolitos chinos, "sprouts", tomates, lechuga y pepinos (2).

Pero, ¿qué hace peculiar a este brote? Son varios los aspectos resaltantes de este brote que han llamado la atención a la comunidad médica y científica del mundo. En primer lugar, lo más llamativo es la severidad de los casos. STEC es una bacteria que puede encontrarse colonizando el intestino sin producir enfermedad; puede producir diarrea aguda de tipo acuosa; pero lo más típico es que produzca diarrea con sangre y en algunos casos colitis hemorrágica. Sólo 5-10\% de los pacientes infectados que presentan diarrea desarrollan días más tarde la complicación severa de HUS. Este síndrome, se caracteriza por la presencia de anemia hemolítica microangiopática, plaquetopenia y falla renal, todo lo que se produce como resultado de un desorden trombótico e injuria endotelial desencadenado por una potente citotoxina, shiga toxina (Sxt1 o Stx2 y sus variantes), presente en las cepas de STEC. En el brote de Alemania, aproximadamente 25\% de los infectados han desarrollado esta complicación, porcentaje muy elevado en relación a otros brotes y casos esporádicos.

En segundo lugar, el HUS es característicamente una enfermedad que afecta mayormente niños menores de 5 años. También puede afectar, pero en menor frecuencia, al adulto mayor, quienes presentan compromiso neurológico con mayor frecuencia que compromiso renal; variante que se conoce como púrpura trombótica trombocitopénica (TTP). El brote de Alemania ha afectado mayoritariamente a personas adultas; más del $80 \%$ de los casos afectados son mayores de 18 años y dos tercios son mujeres (1). No se sabe si esto pueda deberse a factores de adherencia o virulencia de la cepa responsable.

En tercer lugar, el serotipo de STEC mayormente asociado a HUS es el O157:H7, cepa que se caracteriza por ser altamente virulenta y tener el gen que codifica a la proteína intimina (eae), la que facilita la adherencia entre la bacteria y el enterocito, además de tener una o dos de las shiga toxinas, usualmente la Sxt2, que es más tóxica (3). A estas cepas STEC asociadas a enfermedad severa en humanos se les conoce como EHEC. En muchas partes del mundo, predominan los serotipos no-O157, sin embargo la mayoría de los casos esporádicos y casos de HUS se 
asocian a los serotipos O26, O103, O111, O121 y O145. El brote actual corresponde a un serotipo diferente O104:H4, que no está en la lista de los serotipos comunes asociados a HUS (2). Sin embargo, este serotipo ha sido reportado anteriormente en Europa.

En cuarto lugar, usualmente las cepas de STEC, en especial la O157:H7, no están asociados a altos niveles de resistencia antibiótica. La cepa STEC del brote Alemán es resistente a ampiciina, amoxicilina/clavulánico, piperacilina/ sulbactam, piperacilina/tazobactam, cefuroxima, cefoxitina, cefotaxima, ceftazidima, cefpodoxima, estreptomicina, ácido nalidíxico, tetraciclina, y trimetropin/sulfametoxazol. En resumen, esta cepa es productora de betalactamasas de espectro ampliado (BLEE) y es portadora del gen plasmídico $b l a_{\text {СTX-M-15 }}$, que tiene la habilidad de producir enzimas que hidrolizan la cefotaxima (2).

En quinto lugar, y quizás lo más resaltante desde el punto de vista microbiológico, esta bacteria, catalogada como STEC por la presencia de la shiga toxina (Stx2a), tiene una caracterización genotípica bastante peculiar. Esta cepa es negativa a Stx1, negativa a intimina (gen eae) y negativa al gen de enterohemolisina, característicos los dos últimos genes de estar presentes usualmente en las cepas virulentas de EHEC. Por otro lado, la cepa del brote alemán, presenta varios genes típicos de la E. coli enteroagregativa (EAEC), bacteria que se caracteriza por estar asociado a diarrea persistente en niños y por ser una causa importante de diarrea del viajero y diarrea en pacientes VIH. La cepa del brote alemán tiene los siguientes genes de EAEC: aatA (gene de una proteína transportadora), aggR (regulador master de la transcripción), aap (gene de la proteína dispersina), agg (gene de la sub-unidad de la fimbria AAF/I) y aggC (gene de operon de la fimbria AAF/I) (2). Todo esto quiere decir, que al parecer la cepa O104:H4 es una cepa EAEC que adquirió el gen de la Sxt2; sin embargo no se puede descartar que sea en el otro sentido, una cepa STEC que adquirió genes de EAEC. El análisis de las secuencias y la comparación genómica de estas cepas permitirá dilucidar esta interrogante.

E. coli es parte de la flora normal del intestino del ser humano y de muchos animales. Algunas E. coli pueden causar enfermedades extra-intestinales (infección del tracto urinario, bacteriemia y meningitis en los recién nacidos) y otras pueden estar asociadas a gastroenteritis (E. coli diarrogénicas, una de las cuales es STEC). E. coli puede de manera fácil y frecuente intercambiar material e información genética, vía transferencia horizontal de genes (por ejemplo por conjugación, transformación o transducción), con otras bacterias relacionadas, tales como otras cepas patógenas de E. coli, Shigella o Salmonella, e incluso con cepas comensales de E. coli. Esta promiscuidad entre las bacterias, explica como cepas de E. coli pueden presentar características adquiridas de una gran variedad de fuentes, y como cepas comensales pueden evolucionar hacia cepas patogénicas (4) y, como en este caso, a cepas más virulentas.

Theresa J. Ochoa ${ }^{1,2}$

\section{REFERENCIAS BIBLIOGRÁFICAS}

1. European Centre for Disease Prevention and Control. Outbreak of Shiga toxin-producing E. coli in Germany (25 May 2011). URL disponible en: http://ecdc.europa. eu/en/healthtopics/escherichia_coli/epidemiological_ data/Pages/Epidemiological_updates.aspx (Fecha de acceso el 10 de Junio del 2011).
2. European Food Safety Authority (EFSA). Urgent advice on the public health risk of Shiga-toxin producing Escherichia coli in fresh vegetables. EFSA Journal 2011; 9(6):2274.

3. Pennington H. Escherichia coli O157. Lancet 2010; 376(9750):1428-35.

4. Tenaillon O, Skurnik D, Picard B, Denamur E. The population genetics of commensal Escherichia coli. Nat Rev Microbiol 2010; 8(3):207-17.

1 Instituto de Medicina Tropical Alexander von Humboldt, Universidad Peruana Cayetano Heredia, Lima, Perú; Theresa.Ochoa@upch.pe

2 University of Texas School of Public Health, Houston, USA. Theresa.J.Ochoa@uth.tmc.edu 